\title{
ДИСКУРСИВНІ ВИМІРИ ЗАПОВІТУ ЙОСИФА СЛІПОГО
}

У статті визначено мовленнєвий жанр заповіту Йосифа Сліпого як процес і результат текстотвірної діяльності, спрямований на вербалізацію постулатів віри та їхню транспозицію на суспільні питання, актуальні для України. 3'ясовано специбіку заповіту, особливості дискурсивної реалізації оптативності, евідениійності, персуазивності. Схарактеризовано акиентування сакральних смислів у пербормативних та імперативних висловленнях, які сприяють більшому впливу на рецииієнтів. Заповіт містить волю автора, саморефблексію й орієнтири для суспільства, що робить його важливим джерелом для досліджень.

Ключові слова: заповіт, релігійний дискурс, Йосиф Сліпий, дискурсивні параметри, комунікативна иінність, сакральні смисли.

Mostova S. Discursive Dimensions of Josyf Slipyi's Testament. The influence of religion on various spheres of society is extremely important. Analysing Josyf Slipyi's religious heritage, we can trace many spiritual issues that he considered in his works as ascertainment of the status of the Ukrainian Church and its state function. Therefore, it is expedient to study the testament as a communicative activity of Josyf Slipyi, which determines the relevance of our article.

The work aims to study the discursive dimensions in the above-mentioned testament. The main objectives are to determine the theoretical foundations of Josyf Slipyi's religious discourse, to reveal its specifics, functioning, and communicative value of text creation, to characterize the speech genre of the testament in the assertion of Patriarch's faith, to highlight the speech realization in the religious discourse of the testament, its interactivity. The scientific novelty of the obtained results is that the discursive dimensions of Josyf Slipyi's testament have never been characterized before.

This article deals with the discursive parameters of the testament, its structure, and compositional construction. The study defines the speech genre of the testament as a process and result of text-forming activity, aimed at verbalization of faith and transposition to social issues. Josyf Slipyi highlights Christian values and spiritual intentions through the communicative acts, performatives, and imperative constructions that influence recipients.

Distinctive features of the religious discourse of the testament are a high level of persuasiveness, optativity and provability. It also contains the author's will, self-reflection, and guidelines for society. Particular attention is paid to the communicative strategies. The ability to interact, use speech acts, take into account extra lingual factors and apply a wide range of discursive markers ensures audience interest and successful communication. The desire to convey spiritual intentions has led to the 
frequent use of imperative constructions. Evidence is represented in the author's citation of religious texts.

Thus, through the speech genre of the testament, the author affirms faith and values, as well as expresses spiritual intentions. In general, the actualization of communicative peculiarities takes place with the help of linguistic means that provide effective interaction between the speaker and the addressees, representing the author's worldview paradigm.

The religious discourse of the testament describes the church, national and cultural, scientific and socio-political life in Ukraine, which makes it an important source for study, which is needed to identify other discursive parameters of different speech genres of Josyf Slipyi.

Keywords: testament, religious discourse, Josyf Slipyi, discursive parameters, communicative value, sacred meanings.

\section{Вступ}

У сучасній лінгвістиці питання релігійної комунікації набувають ширшого розгляду та осмислення (Мечковська, 1998), зокрема в дискурсивному аспекті визначено особливості синергійності релігійного дискурсу в проповіді та молитві, а також ритуального релігійного дискурсу (Кравченко, 2017), схарактеризовано поняття релігійної дискурсивної особистості (Савелюк, 2019), з'ясовано структурнофункціональні ознаки релігійного дискурсу (Одарчук, \& Приварська, 2008), його комунікативні параметри (Бацевич, 2010; Карасик, 2002), лінгвофілософські засади (Антіпова, 2016) та ін.

Творчий доробок Йосифа Сліпого, українського церковного й громадського діяча, Предстоятеля Греко-Католицької Церкви, був предметом дослідження мовознавців і теологів (Т. Грушева, I. Дацько, О. Петришина, I. Хома). Ці праці розкривають різні аспекти мовотворчості Йосифа Сліпого, проте проповіді, промови та заповіт Патріарха досі залишаються неопрацьованими в дискурсивному плані.

Аналізуючи його релігійну спадщину, можемо простежити низку духовних питань, які він осмислював у своїх працях, оскільки завжди намагався зорганізувати церковний простір України, активно працював над розбудовою УГКЦ, утверджував віру та моральні цінності. Передусім Патріарх чітко окреслює свою позицію щодо статусу української церкви та ії державної функції. Тож доцільним є розгляд релігійного дискурсу Йосифа Сліпого, що й зумовлює актуальність нашого дослідження. 
Метою роботи є дослідження дискурсивних вимірів заповіту Йосифа Сліпого. Основні завдання статті: 1) обгрунтувати теоретичні засади вивчення релігійного дискурсу Йосифа Сліпого, його специфіку, функціонування та комунікативну цінність текстотворення; 2) схарактеризувати мовленнєвий жанр заповіту в утвердженні віри Патріархом; висвітлити мовленнєву реалізацію в релігійному дискурсі заповіту.

Матеріалом дослідження слугує заповіт Йосифа Сліпого за публікацією «Будьмо собою: життя і заповіт патріарха Йосифа Сліпого» (Турій, 2017).

Наукова новизна отриманих результатів полягає в тому, що вперше схарактеризовано заповіт Йосифа Сліпого як процес і результат текстотвірної діяльності, спрямований на вербалізацію постулатів віри та їхню транспозицію на суспільні питання, з'ясовано мовленнєву реалізацію дискурсивних категорій.

\section{Методи дослідження}

У процесі аналізу релігійного дискурсу потрібно зважати на тематичну, комунікативну та структурну єдність. Саме тому релевантним для характеристики заповіту є метод дискурс-аналізу, за яким текстотворення досліджується у зв'язку з різними позамовними процесами. Осягнення духовних смислів у спадщині Патріарха можливе завдяки застосуванню герменевтичного методу. Метод лінгвокультурологічного аналізу доповнив міждисциплінарний характер дослідження.

\section{Виклад основного матеріалу}

У лінгвістичних працях релігійний дискурс тлумачать «як різновид інституційного дискурсу, що розкриває історично та соціокультурно регламентовану смислотвірну діяльність, спрямовану на трансляцію постулатів віри та прилучення вірян до системи релігійних поглядів» (Олешко, 2017: 27), мета якого - «у прилученні до віри в межах певної конфесії (щодо проповіді це заклики до віри і покаяння, повчання та утвердження у вірі й чеснотах, роз'яснення віровчення)» (Карасик, 2002: 223).

Мовленнєвий жанр заповіту розглядають як «текст перформативного характеру з логічно послідовними мовленнєвими актами, які 
мають ілокутивну силу і втілюють дію заповідання» (Кулина, 2019: 153-183).

У нашому дослідженні розуміємо заповіт Йосифа Сліпого як процес і результат текстотвірної діяльності, що спрямований на вербалізацію постулатів віри та їхню транспозицію на суспільні питання крізь призму віри, досвіду, настанов автора для досягнення впливу на вірян. У цьому заповіті реалізовано елементи подяки, молитви, пробачення та ін.

Заповіт, який Йосиф Сліпий писав упродовж одинадцяти років, реалізується в монологічній формі й передає інтенцію у волевиявленні автора: Якщь такою буде Воля Божа і бажання Українського Божого люду, складіть мою домовину в підземеллях оновленого Собору Святої Собіï (Турій, 2017: 70). Воля заповідача стосується не матеріального майна, а духовних надбань, адже душа Патріарха знайде спочинок тільки в “оновленому Соборі”, що означає об”єднану Київську церкву та єднання українського народу загалом. Таке усвідомлення вплинуло на мовленнєву поведінку автора, який уважав за необхідне зміцнювати духовні засади та світоглядні орієнтири суспільства.

“Завіщання” відбувається від першої особи однини, хоча досить часто особовий займенник “я” опущено: ...ще раз благаю, наказую i заповідаю тобі, моє Духовне стадо (Турій, 2017: 57). Оскільки текст заповіту звернено до християн, то часто вживається інклюзивне “ми": Всі ми, католики і православні, боремося за повстання нашої Церкви іза ії духовну силу в Україні і в країнах поселення наших вірних. I всі ми несемо важкий Господній хрест, сповідуючи Христа (Турій, 2017: 61). Таке узагальнення підкреслює, що Патріарх звертається до кожного й водночас до широкої аудиторії.

“Завіщання” починається формулою-присвятою, що цілком відповідає цьому мовленнєвому жанру та окреслює коло читачів: Моїм Духовним Дітям, Владикам, Священникам, Монахам і Монахиням і всім Вірним Украӥнської Католицької Церкви Мир у Господі й архієрейське благословення! (Турій, 2017: 33). Текст присвяти містить вказівку на адресованість читачам і дає благословення. Такий приклад $€$ сакральним текстом, що описує священне дійство.

Особливістю текстотворення заповіту є згадування біографічних деталей життя його автора. Наприклад, яку роль відіграє виховання та як сім'я формує світоглядні принципи. Патріарх неодноразово 
згадує, що саме родина прищепила любов до Христа: Насамперед, у юних роках, був я добровільним Його в'язнем! Бо народився я $і$ був вихований в українській християнській, хліборобській, глибоко віруючій родині. Вона передала мені та защепила в мені віру в Христа i любов до Нього! (Турій, 2017: 35). Отже, Йосиф Сліпий показує реципієнтам соціокультурні чинники, що мали вплив на його духовне становлення. Звернення до спогадів, пояснення реалій буття чи минулого встановлює зв'язок між мовцем і аудиторією: Ось так ступив я на тернистий шлях мого подальшого життя (Турій, 2017: 39). Наративізація досвіду Патріарха досягає впливу на вірян, а словосполучення “тернистий шлях" суголосне його життєвому кредо «Per aspera ad astra».

Як відомо, у релігійному дискурсі часто апелюють до сакральних текстів. Вони сприймаються як такі, що не потребують пояснення, адже зрозумілі мовцям. Іноді певні фрагменти заповіту нагадують молитву, що цілком очевидно, зважаючи на релігійність автора: ...Третьої Божої Особи у Пресвятій Тройці, Духа Святого, Духа істини, Утішителя та Життя Подателя, щзо все сповнює, щцо в нас і у Христовій Церкві невидимо перебуває (Турій, 2017: 37). У цьому прикладі бачимо паралель із молитвою «Символ Віри», а також «Царю Небесний». Звісно, рівень знань реципієнтів не $є$ однаковим, проте очікується, що вони свідомо вірять в істини, висловлені Патріархом, або ж володіють тими знаннями, що й мовець. Зауважимо, що в процесі комунікації інтеракційність забезпечує врахування того типу “фонових знань”, які спроєктовані на широке соціально-культурне тло (Ніка, 2003: 8-15).

“Заповідаю” є характерним перформативом для заповіту: Отож заповідаю вам усім: моліться, працюите $і$ боріться за збереження християнської душі кожної людини украӥнського роду... (Турій, 2017: 61).

Важливим елементом заповіту є оптативність, що характеризує бажання і транслює інтенцію автора. Як зазначалося, воля мовця виражається через перформативи: Отож заповідаю вам усім. Так у жанрі заповіту Йосиф Сліпий утверджує свою віру й висвітлює християнські цінності.

Прагнення донести до вірян духовні інтенції зумовило частотність імперативних конструкцій: Тому заповідаю вам: моліться... 
(Турій, 2017: 61), що є важливими в заповідальному текстотворенні. Спонукання до дії продуктивно виражено дієсловами-предикатами 2-ої особи множини (збережіть, оновіть та ін.): Отож, заповідаю вам: відроджуйте їх і рятуйте їх в Украӥні й у всіх краӥнах поселення нашого Украӥнського народу! (Турій, 2017: 37). Такий повтор імператива додає емоційності й підсилює спонукання тексту. Йосиф Сліпий очікує, що реципієнти зможуть здійснити накази в майбутньому, тож звертання до аудиторії не бути пасивними, не боятися відповідальності й заклик до дії виправдані.

Евіденційність репрезентована в цитуванні автором релігійних текстів. «Завіщання» починається з цитації Євангелія. Вибрані Патріархом рядки свідчать про глибоке співвіднесення тексту Святого Письма з почуттями та переживаннями автора: «Ще трохи, i світ мене вже не побачить» (Ів. 14, 19), бо «надходить година, коли вже і притчами не промовлятиму до вас...» (Ів. 16, 25). Патріарх вибирає схожі цитати з різних глав Євангелія, у такий спосіб ділиться своїм досвідом прочитання. Йосиф Сліпий вивчав, обдумував Святе Письмо, щоб зрозуміти, як Господь діє в його житті. Наприклад, у заповіті міститься згадка про Боже провидіння: У покликанні служити Христові в духовному стані виразно бачу Божу руку. Відчувши в ньому Господній Голос і підтримуваний Господньою десницею, радів я, що міг упродовж кількох десятків років життя працювати як добровільний в'язень Христа: як Його служитель, як науковець, богословський дослідник... (Турій, 2017: 37). Розуміння Святого Письма потребує духовної праці, щоб утверджувати віру людей у Божу присутність.

Відповідно до проведеного аналізу можна простежити, що Йосиф Сліпий не змінює канонічних євангельських цитат, а строго дотримується оригіналу прецедентних текстів, майстерно вплітає фрагменти євангельських висловлень у текстову канву заповіту: ... ще раз благаю, наказую і заповідаю тобі, моє Духовне стадо: «Браття, як діти світла ходіть... I не беріть участи в безплідних ділах тьми, але радше засуджуйте їх, бо що вони й творять, соромно є й говорити...» (Еф. 5:8, 11). Ще і ще благаю вас усіх: "Будьте печаттю мого апостольства» (I Кор. 9, 2), «бодріться, стійте в вірі, будьте мужні...» (I Кор. 16, 13) (Турій, 2017: 57). Тут бачимо структуру: заповідаю - кому - що, яка $є$ ключовою для заповіту. Так розкривається структура семантичних відношень релігійного дискурсу. Звернення Йосифа Сліпого 
до прецедентного тексту також трансформується: ...щоб привітатися поцілунком миру та обнятись у братній любові! (Турій, 2017: 61). За Євангелієм, поцілунок Юди Іскаріота символізує зраду, проте автор заповіту використовує “поцілунок миру”, у такий спосіб творює метатекстову алюзію й надає висловлюванню потрібної комунікативної спрямованості.

Текстам релігійного дискурсу притаманна конкретна вказівка на джерело, що яскраво демонструє такий приклад: «...сидячи на санях на дорозі в далечінь, знеможеним голосом молитву мовлю» (Повч. Володимира Мономаха дітям) і вам, моїм Духовним чадам, заповідаю (Турій, 2017: 43). Патріарх усвідомлює, що згадана цитата вимагає певних підказок для розуміння релігійного дискурсу, тож зазначає покликання, яке засвідчує інтертекстуальні зв'язки та дискурсивну категорію евіденційності.

Упродовж заповіту бачимо наскрізну нитку цитування «Повчання дітям» Володимира Мономаха: Сидячи на санях, помислив я в душі своїй і воздав хвалу богові, що він мене [до] сих днів, грішного, допровадив. Тобто ці слова вказують на те, що Володимир Мономах $€$ значущою мовною особистістю для Йосифа Сліпого, оскільки «Повчання...» написане в поважному віці, як і заповіт.

Цитування Президента італійської Посольської Палати Юлія Андреотті виконує аргументаційну функцію в заповіті: На превелике щзастя, Ви є “померлий”, що говорить, і не тільки той, хто говорить, але такий, що творить... (Турій, 2017: 47). Тобто йдеться про становище християнства в Радянському Союзі. У цьому прикладі можна простежити пресупозицію - спільний фонд знань, досвід та відомості, якими володіють комуніканти, тому наведена цитата сприймається переконливо.

У заповіті є самоцитування, де автор зазначає вказівку на джерело. Наприклад: Наука є «остоєю для Церкви в нашім народі», вона через іï навчальні та виховні установи є "виховницею народу», бо через неї одиниия стає тим багатіша, чим сильніше опановує ії ідея, що обнімає небо і землю, час і вічність, історію і сучасність, серие і ум...» (пор. моє «Слово на відкритті Богословської Академї» 6 жовтня 1929 р.). (Турій, 2017: 39). Цитація Патріархом власного висловлення $є$ процесом дискурсивного мислення: «Ми стоїмо безповоротно на патріярхальному устрої нашої Церкви», сказав я у своєму слові на закінчення 
нашого Синоду в 1969 р. (див. Благовісник. - Кн. 1-4. - 1969. - С. 120) (Турій, 2017: 59). Йосиф Сліпий спонукає реципієнтів до подальшого сприйняття інформації та зацікавлює їх ознайомитися з іншими додатковими матеріалами.

Останній абзац заповіту містить завершальну формулу, що перегукується з текстами послань апостолів, наприклад: Благодать вам та мир від Бога, Отиянашого, і Господа Ісуса Христа!

Учасники релігійної комунікації мають володіти відповідними стратегіями, спрямованими на досягнення інтенції - прилучення вірян до релігійних поглядів. Уміння взаємодіяти з релігійною спільнотою в трансляції постулатів віри, враховувати екстралінгвальні чинники й застосовувати широкий спектр дискурсивних маркерів забезпечує інтерес аудиторії й успішну комунікацію.

\section{Висновки}

У роботі визначено мовленнєвий жанр заповіту як дію перформативного характеру. Заповіт Йосифа Сліпого схарактеризовано як текстотвірну діяльність, що спрямована на вербалізацію сакральних сенсів та їхню транспозицію на актуальні суспільні питання. Комунікативна цінність заповіту полягає в наративізації досвіду, вербалізації духовних інтенцій та утвердженні віри у творчій спадщині Патріарха. Дискурсивні виміри заповіту уконкретнюються у творенні смислів евіденційності, оптативності, імперативності, що набувають ваги для досягнення інтерактивності автора і вірян.

Перспективи дослідження - у розширенні вивчення дискурсивних параметрів заповіту Йосифа Сліпого, а також здійсненні дискурсивного аналізу його промов і проповідей, що дасть змогу з'ясувати характерні для релігійного дискурсу ознаки, а також уточнити їхню реалізацію в різних мовленнєвих жанрах.

\section{ЛIТЕРАТУРА}

1. Антіпова, О. П. (2016). Лінгвофілософські засади сучасного релігійного дискурсу. Вісн. Наи. авіа. ун-ту. Серія «Філософія. Культурологія», 2, 36-39. 2. Бацевич, Ф. С. (2010). Нариси з лінгвістичної прагматики. Львів: ПАІС. 3. Карасик, В. И. (2002). Языковой круг: личность, концепты, дискурс. Волгоград: Перемена. 4. Кравченко, Н. О.(2017). Синергійність англомовного релігійного дискурсу (теолінгвістичний підхід). Одеса: КП ОМД. 5. Кулина, О. В. (2019). Заповіт як соціокомунікативний феномен (на матеріалі англійських заповітів середини XIX - початку XXI століть). 
(Автореф. дис. ... канд. філол. наук). Львів: Львів. нац. ун-т імені Івана Франка. 6. Мечковская Н. Б. (1998). Язык и религия. Москва: ФАИР. 7. Ніка, О. І. (2003). Модальність як категорія дискурс-аналізу. Актуальні проблеми української лінгвістики: теорія і практика, 8, 8-15. 8. Одарчук, Н. А., \& Приварська, Н. П. (2008). Структурно-функціональні особливості релігійного дискурсу. Наук. вісн. Волин. наи. ун-ту імені Лесі Українки. Розділ 1: Дискурсознавство, 5, 44-48. 9. Олешко, Ю. Л. (2017). Староукраїнська проповідь XVII ст. у комунікативно-когнітивному вимірі. (Автореф. дис. ... канд. філол. наук). Київ: КНУ імені Тараса Шевченка. 10. Савелюк, Н. (2019). “Релігійна особистість” і “релігійна дискурсивна особистість”: структурний та динамічний виміри суб'єкта релігійної віри. Теоретичні і прикладні проблеми психологіi, 1, 216-227. 11. Турій, О. (Укл.). (2017). Будьмо собою: життя і заповіт патріарха Йосифа Сліпого. Львів: Вид-во УКУ.

\section{REFERENCES}

1. Antipova, O. P. (2016). Linhvofilosofski zasady suchasnoho relihiinoho dyskursu [Linguo-philosophical principles of the modern religious discourse]. Visn. Nats. aviats. untu. Seriia «Filosofiia. Kulturolohiia» - Bulletin of the National Aviation University. Series «Philosophy. Culturology», 2, 36-39 [in Ukrainian]. 2. Batsevych, F. S. (2010). Narysy z linhvistychnoi prahmatyky [Essays on linguistic pragmatics]. Lviv: PAIS [in Ukrainian]. 3. Karasik, V. I. (2002). Yazykovoy krug: lichnost', kontsepty, diskurs [Language circle: personality, concepts, discourse]. Volgograd: Peremena [in Russian]. 4. Kravchenko, N. O. (2017). Synerhiinist anhlomovnoho relihiinoho dyskursu (teolinhvistychnyi pidkhid) [Synergy of English religious discourse]. Odesa: KP OMD [in Ukrainian]. 5. Kulyna, O. V. (2019). Zapovit yak sotsiokomunikatyvnyi fenomen (na materiali anhliiskykh zapovitiv seredyny XIX - pochatku XXI stolit) [Testamentas a socio-communicative phenomenon]. Extended abstract of candidate's thesis. Lviv: Lviv. nats. un-t imeni Ivana Franka [in Ukrainian]. 6. Mechkovskaya, N. B. (1998). Yazyk i religiya [Language and Religion]. Moskva: FAIR [in Russian]. 7. Nika, O. I. (2003). Modalnist yak katehoriia dyskurs-analizu [Modality as a category of discourse analysis]. Aktualni problemy ukrainskoi linhvistyky: teoriia i praktykaModality as a category of discourse analysis, 8, 8-15 [in Ukrainian]. 8. Odarchuk, N. A., \& Pryvarska, N. P. (2008). Strukturno-funktsionalni osoblyvosti relihiinoho dyskursu [Structural and functional features of religious discourse]. Nauk. visn. Volyn. nats. un-tu imeni Lesi Ukrainky. Rozdil 1: Dyskursoznavstvo - Scientific Bulletin of Lesya Ukrainka Volyn National University. Section 1: Discourse Studies, 5, 44-48 [in Ukrainian]. 9. Oleshko, Y. L. (2017). Staroukrainska propovid 17 st. u komunikatyvno-kohnityvnomu vymiri [Old Ukrainian Sermon of the 17th Century in Communicative and Cognitive Dimension]. Extended abstract of candidate's thesis. Kyiv: KNU imeni Tarasa Shevchenka [in Ukrainian]. 10. Saveliuk, N. (2019). "Relihiina osobystist" i "relihiina dyskursyvna osobystist": strukturnyi ta dynamichnyi vymiry subiekta relihiinoi viry ["Religious personality" and "religious discursive personality"]. Teoretychni i prykladni problemy psykholohii - Theoretical and applied problems of psychology, 1, 216-227 [in Ukrainian]. 11. Turii, O. (Ed.). (2017). Budmo soboiu: zhyttia i zapovit patriarkha Yosyfa Slipoho [Let us be ourselves: the life and testament of Patriarch Josyf Slipyj]. Lviv: Vyd-vo UKU [in Ukrainian]. 
Мостова Софія Михайлівна - філолог I категорії, завідувач «Музею-форуму Олеся Гончара», Інститут філології Київського національного університету імені Тараса Шевченка; вул. М. Ломоносова, 45, м. Київ, 03022, Україна.

Tel.: +38-097-801-49-47

E-mail: mostovasophiya99@gmail.com

https://orcid.org/0000-0001-9467-2585

Mostova Sofiia Mykhailivna - Philologist of the Ist category, Head of Oles Honchar Museum Forum, Institute of Philology, Taras Shevchenko National University of Kyiv; 45 M. Lomonosova Str., Kyiv, 03022, Ukraine.

Надійшла до редакції 1 вересня 2021 року

\section{Citation}

ДСТУ 8302:2015: Мостова С. М. Дискурсивні виміри заповіту Йосифа Сліпого. Лінгвістичні дослідження: зб. наук. пр. Харк. нац. пед. ун-ту імені Г. С. Сковороди. Харків, 2021. Вип. 55. С. 105-114. DOI: https://doi.org/10.34142/23127546.2021.55.10

APA: Мостова, С. М. (2021). Дискурсивні виміри заповіту Йосифа Сліпого. Лінгвістичні дослідження, 55, 105-114. DOI: https://doi.org/10.34142/23127546.2021.55.10 